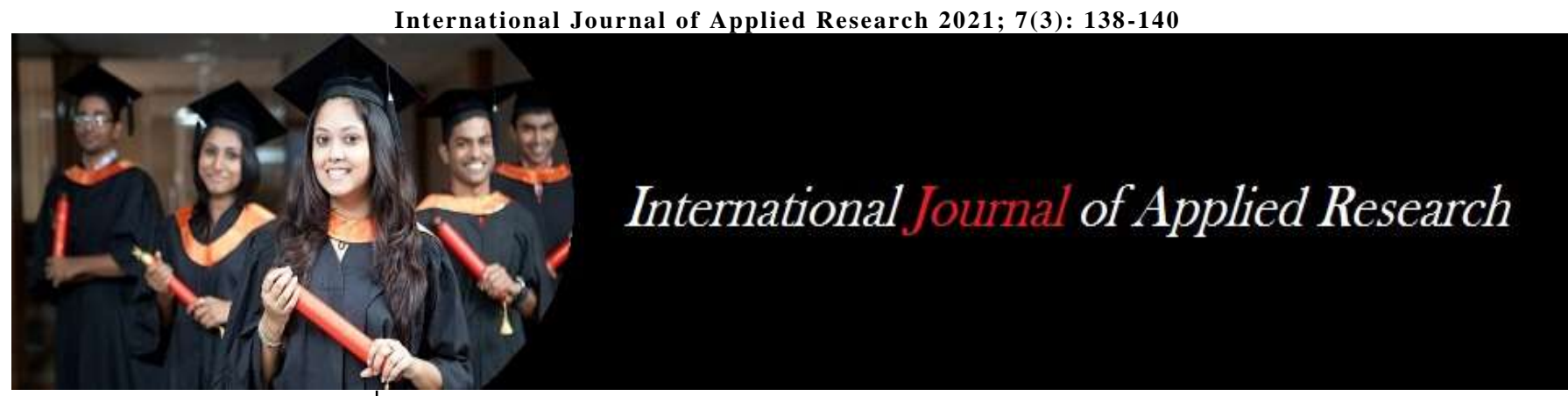

ISSN Print: 2394-7500

ISSN Online: 2394-5869

Impact Factor: 8.4

IJAR 2021; 7(3): 138-140

www.allresearchjournal.com

Received: 08-01-2021

Accepted: 11-02-2021

Dr. Shweta Singh

Assistant Professor, English,

K.M.G.G.P.G. College,

Badalpur, Gautam Budh

Nagar, Uttar Pradesh India
Corresponding Author:

Dr. Shweta Singh

Assistant Professor, English,

K.M.G.G.P.G. College,

Badalpur, Gautam Budh

Nagar, Uttar Pradesh India

\section{Patriarchy-a tool for men-women subjugation-an analysis of bell hooks' 'understanding patriarchy}

\section{Dr. Shweta Singh}

DOI: https://doi.org/10.22271/allresearch.2021.v7.i3c.8383

\section{Abstract}

Patriarchy can be defined as a social organisation manifested by the supremacy of the male members in the clan or family and dependant status of female members. The concept of patriarchy incorporates all the socio-political mechanisms which replicate and exert male dominance over women. Fixating on real and perceived biological differences between the two recognised sexes, men justify their domination on the basis of an alleged biological inferiority of women. There are different models of patriarchy at different times and in different cultures and places but the lower value given to women and their roles as compared to men and their roles, remains constant in all models. But interestingly, Bell Hooks' essay 'Understanding Patriarchy' completely deconstructs this very neat binary between the male perpetrator and female victim. In this essay, Bell Hooks emphasises the need to focus on the core problem of patriarchy which affects all people irrespective of their genders. Patriarchy is a disease which infect both men and women.

Keywords: Patriarchy, dominance, men, women, gender, politics, violence

\section{Introduction}

Bell Hooks discusses the politics of patriarchy in this essay which completely deconstructs the ontology of victimhood inside patriarchal system. Patriarchy is not simply a discursive phenomenon but experiential phenomenon, too. Generally, women are thought to be the silent sufferers of patriarchal society and men are excluded from this tormented class because they uphold the position of victimizers. Bell Hooks delineates a different aspect of this conventional description of patriarchy where men and women equally share the victim role. People talk about gender inequality, gender abuse, male abuse on woman etc. but they seldom locate the core problem of these reasons, that is patriarchy. This essay does away with the dualism of male abuser and female abused through real lived experiences and, thus, establishes patriarchy as a lived reality and not simply a textual construct. Patriarchy is constructed and consolidated in different kinds of illogical institutional apparatus:

"Patriarchy is the single most life-threatening social disease assaulting the male body.......Most men never think about patriarchy-what it means, how it is created and sustained...... Men who have heard and know the word usually associate it with women's liberation, with feminism, and therefore dismiss it as irrelevant to their own experiences." (P.1)

Patriarchy takes the form of medical metaphor here and Hooks tells us that the victim of patriarchy is the male body first and then, men are indoctrinated to become the perpetrator of patriarchy. Like any grand narrative, patriarchy is consumed unquestioningly.

\section{Psychological Terrorism}

For men patriarchy is axiomatically related to feminism and females only and they do away themselves with it completely. Gender dynamics are operative at daily level and they are not just a part of academic discourse. Men are unwilling to indulge themselves in the discussion of patriarchy because patriarchy is not always an evil but it can be benevolent, too. Male violence and male abuse are very derogatory terms inside gender politics but the term patriarchy becomes very ambiguous and tricky. This divorce of feminism from the everydayness is a result of refusal to acknowledge patriarchy. Bell Hooks gives a very anecdotal evidence from her own childhood to corroborate the problems: 
"The patriarchy is a political social system that insists that males are inherently dominating, superior to everything and everyone deemed weak, especially females and endowed with the right to dominate and rule over the weak and to maintain that dominance through various forms of psychological terrorism and violence." (P.1)

Violence and terrorism are not just corporeal but they also become psychological, structures of fear that are sort of injected in the minds of people who are expected to be conformist to patriarchy. Patriarchy is operative in different disguises in different institutions.

\section{Family}

Family becomes a particularly important unit. Hooks gives a graphic description of her own family in terms of how patriarchy was produced and promoted by the familial figures with authority. House becomes a micro model for patriarchal operation and this model is replicated in more macro spaces like nation, religion etc:

"When my older brother and I were born with a year separating us in age, patriarchy determined how we would each be regarded by our parents." (P.1)

The very moment of birth-as a girl or boy, determines your behavioural aspect. The female child is brought up in a way which is distinctly different from the way the male child is brought up and the entire politics of parenting relies on certain patriarchal parameters. The parents are indoctrinated to spin the wheel of patriarchy. The toys of children are the most innocuous things but the design of toys become profoundly patriarchal in quality. Girls are supposed to play with dolls and kitchenware whereas boys are given guns to train them into violence, therefore, even ludic performances become discursive in quality. Marbles were considered a game belonging to boys in 50s. Hooks was better at playing marbles than her brother and it became problematic for her father who was an authoritative figure at home. He could not tolerate how his daughter could be a better player than his son in a game that was designed for men. He corporeally abused his daughter for it and confined her to a room to teach her a lesson. To be competitive and aggressive are stereotypically manly attributes which the girl child here seems to be appropriating and it becomes a problem to the very patriarchal father figure:

"Our family sat spellbound, rapt before the pornography of patriarchal violence." (P.2)

Surprisingly, none even her mother dares stand against this violence. Instead, her mother reinforces the authority of the father by comforting the girl child by saying that Dad had done the right thing. Thus, the family space becomes almost like a battleground of codes of conduct and reluctance to the conformation of these codes of conduct calls for punishment.

\section{Religion}

Religion plays a pivotal role in the indoctrination of patriarchy. Patriarchy finds a big ally in religion which is profoundly patriarchal in quality. Hooks was brought up in an American family which believed in patriarchy promoted by religion:

"At church they had learned that God created man to rule the world and everything in it and that it was the work of women to help men perform these tasks, to obey, and to always assume a subordinate role in relation to a powerful man. They were taught that God was male." (P.1)
God created woman as an afterthought to be a partner of the man, to conform to the desire and wishes of the man. These teachings were reinforced in every institution her parents encountered-schools, sports-houses, clubs as well as churches and it seemed like a natural way to organise life. Like any grand narrative, patriarchy, too, operates through naturalisation. Women are supposed to stay indoors, to protect the house. They are supposed to be a nurturer and a caretaker whereas the male child is supposed to go out and rule the world. If a woman does not conform to these roles assigned, it is considered as an unnatural behaviour. And if a man does not act accordingly, his behaviour is considered as unnatural. Hooks' brother was taught that he should learn violence outside home because it is a great virtue for a boy to be violent in certain appropriate settings. Settings becomes particularly important category in gender, especially in relation to identity and agency. When it comes to male expressions, the public space becomes important whereas for women, this space is restricted to the interior, that is the kitchen, the drawing room, the bedroom etc. He was taught that a boy should not express feelings while Hooks was taught that she should express feelings. When a man handles adversity stoically without expressing emotions, he is categorised as a strong male. She was taught that:

"...rage was not an appropriate feminine feeling, that it should be not only not be expressed but be eradicated." (P.1) Rage becomes a male feeling. Women are expected to suppress their feelings of rage and be meek and submissive. Bell Hooks was stronger and more violent than her brother since childhood and it was undesirable attitude on her part according to her parents. Her brother was gentle and peaceful boy and it was awfully bad on his part because a boy should be assertive and agentic:

"We both learned the word patriarchy in our adult life, when we learned that the script that had determined what we should be, the identities we should make, was based on patriarchal values and beliefs about gender." (P.1)

Hooks is obvious here that we are supposed to follow a particular pattern of behaviour constructed by patriarchy and become passive agents enacting that particular script. There is a certain script for a male child, another script for a female child. She was very vocal against patriarchy because this system meant to facilitate her brother and it was denying her certain privileges which she coveted.

\section{Indoctrination into Patriarchy}

Bell Hooks gives an anecdotal reference of a therapist Terrence Real who, despite his best efforts, could not save his sons from the typical patriarchal codes of conduct. His young son Alexander loved to play with barbie dolls but this behaviour was unacceptable from a boy who was supposed to play manly games. The little boy had to face the gaze of his friends so much so that he ultimately stopped playing with dolls and started behaving like the society expected. This is called normal traumatization. It is a traumatization which is meant to create normalcy. So, to indoctrinate boys into the rules of patriarchy, we force them to feel pain and deny their feelings. Hooks is of the view that real victims of patriarchy are boys who are forced to move away from their feelings and are made to appropriate hardcore patriarchal rules.

We are experientially schooled into the art of patriarchy. Patriarchy becomes a psychological condition where you are 
trained to think in certain ways. Most people continue to see men as the problem of patriarchy but women can be as wedded to patriarchal thinking and action as men. "The contemporary presence of female headed household has leaded many people to assume that children in these household are not learning patriarchal values because no male is present." (P.2) It is erroneous to assume that men are the sole teachers of patriarchal thinking, yet female headed households endorse and promote patriarchal thinking with far greater passions than two parent households. Patriarchy is perpetuated by men as well as by women. Women can be as patriarchal, perhaps more patriarchal on some occasions because "they do not have experiential reality to challenge false fantasies of gender roles." (P.2) In such households women sometimes tend to romanticize the patriarchal absent male. Patriarchy is a system which is supported equally by men and women.

\section{Conclusion}

In this essay Hooks looks at the entire complexity of patriarchy as an operation. It becomes a more complex and inclusive model, where men and women become collaborators and colluders. Patriarchy operates in overt and covert ways. As long as we do not locate the problem as patriarchy, it is going to be exceedingly difficult to dismantle it. We hear about sexist violence in public discourses about rape and abuse but the most common form of patriarchal violence happens inside home. Hooks asserts that we need to locate the problem at the very beginning and nip it in the bud. Children are born into a system which indoctrinates them psychologically and emotionally. This is a deeper form of violence and it needs to be addressed. The point of such violence is usually to reinforce a dominator model in which the authority figure is deemed ruler over those without power and given the right to maintain the rule through the practices of subjugation. And like any grand narrative, the best way for patriarchy to operate is to create consensual collaborators. To withhold the truth, not to talk about what happens in the family, these are covert systems through which children are taught to be patriarchal. This silence promotes denial, so, if we cannot name a system, we cannot question it. Patriarchy is so deep seated in our psyche that we feel reluctant to talk about it. Throughout the essay, Hooks keeps on saying that patriarchy is almost a pathological condition which affects men and women, perhaps men more than women because men become consumers of patriarchy which effaces their agency. We need to move away from this model of man being the enemy and work collaboratively to destroy this evil.

\section{References}

1. Understanding Patriarchy. https://imaginenoborders.org/pdf/zines/UnderstandingP atriarchy.pdf. 9 March, 2021. 